\title{
Study on Financial Performance Analysis at Pupa Home Care Pvt. Ltd
}

\author{
N Indhu ${ }^{1} \mid$ K Malarkodi ${ }^{1}$
}

${ }^{1}$ Department of Management, M Kumarasamy College of Engineering, Karur, Tamilnadu, India.

\section{To Cite this Article}

N Indhu and K Malarkodi, "Study on Financial Performance Analysis at Pupa Home Care Pvt. Ltd", International Journal for Modern Trends in Science and Technology, Vol. 06, Issue 07, July 2020, pp.:100-105; https://doi.org/10.46501/IJMTST060716

Article Info

Received on 17-June-2020, Revised on 21-June-2020, Accepted on 31-June-2020, Published on 17-July-2020.

\section{ABSTRACT}

Financial Performance in broader sense refers to the degree to which financial objectives being or has been accomplished and is an important aspect of financial growth. It is the method of calculating the results of a firm's policies operations in monetary terms. The main objective of financial performance analysis to $\mathrm{know}$ the financial health undertaking and to know the earning performance of the organization and to provide the company with appraise for investment opportunity or potentiality. This analysis is from the secondary data collected from the annual report. This project deals with the financial performance to know the growth rate for the past five years. The ratio analysis, comparative analysis and trend analysis are the tools to analyze the financial performance of the company Pupa home care pvt.ltd.

KEYWORDS: Comparative analysis, Performance, Ratio analysis

Copyright (C) 2020 International Journal for Modern Trends in Science and Technology

DOI: https://doi.org/10.46501/IJMTST060716

\section{INTRODUCTION}

Financial statements contain a wealth of information, which if properly read, analyzed or interpreted can provide valuable insights into a firm's performance and position. Also it is the starting point for making plan, before using any sophisticated forecasting and planning procedure. By analyzing these statements, firm can evaluate its past, present, projected performance etc. Usually management would be particularly interested in knowing the financial strength of firm to make their best use and to be able to spot out the financial weakness of the firm to take suitable corrective action. The future plan of the firm should be laid down in view of the firm's financial strength and weakness. In short, through financial analysis and interpretation it helps effectively the user for decision-making process.

\section{REVIEW OF LITERATURE}

Campbell (2008) constructed a multivariate prediction model that estimates the probability of bankruptcy reorganization for closely held firms. Six variables were used in developing the hypotheses and five were significant in distinguishing closely held firms that reorganize from those that liquidate. The five factors were firm size, asset profitability, the number of secured creditors, the presence of free assets, and the number of under-secured secured creditors. The prediction model correctly classified $78.5 \%$ of the sampled firms. This model is used as a decision aid when forming an expert opinion regarding a debtor's likelihood of rehabilitation. No study has incorporated the financial performance analysis of the central public sector enterprises in Indian drug $\&$ pharmaceutical Industry. Nor has any previous research examined the solvency position, liquidity 
position, profitability analysis, operating efficiency and the prediction of financial health and viability of public sector drug $\&$ pharmaceutical enterprises in India.

Satyanarayana Chary and Sampath Kumar (2011) discussed in their article that working capital is one of the vital decisions of financial management function. Profitability and working capital relationship is frequently emphasized for deciding on the level of investment in working capital. All manufacturing firms need to understand the association between these two variables to arrive at optimal financial decisions. Though theories exist on the topic, empirical methods are inadequately focused in arriving at conclusions. Use of statistical methods in understanding the relationship is systematic and scientific, which may provide better insight for decision making.

\section{Research design}

\section{METHODOLOGY}

This study is based on secondary data. Data pertaining behaviour of profitability position of the company by using the balance sheet and profit $\&$ loss account of Pupa Homecare pvt.ltd.

\section{Nature of data}

The data required for the study has been collected from secondary data from the annual report.

\section{Tools applied}

The following tools were made for the study:

Trend analysis

Ratio analysis

Comparative statement

\section{Limitations of the study}

The analysis was made with the help of the secondary data collected from the annual report company.

All the limitations of ratio analysis, common-size statement, comparative statements, and trend analysis and interpret are applicable to this study. The study is only 5 years from 2014-2015 to 20018-19.

\section{DATA ANALYSIS AND INTERPRETATION}

\subsection{Current Ratio}

Current ratio may be defined as the relationship between current assets and current liabilities it is the most common ratio for measuring liquidity. It is calculated by dividing current assets and current liabilities. Current assets are those, the amount of which can be realized with in a period of one year.
Current liabilities are those amounts which are payable with in a period of one year.

Table No. 4.1 Current Ratio

\begin{tabular}{|c|c|c|c|}
\hline Year & $\begin{array}{c}\text { Current } \\
\text { Asset }\end{array}$ & $\begin{array}{c}\text { Current } \\
\text { Liabilities }\end{array}$ & Ratio \\
\hline $2014-2015$ & 3634315.50 & 3662645.02 & 0.99 \\
\hline $2015-2016$ & 2910844.42 & 4344770.10 & 0.66 \\
\hline $2016-2017$ & 8096618.55 & 3055104.10 & 2.65 \\
\hline $2017-2018$ & 10853034.28 & 5037069.34 & 2.15 \\
\hline $2018-2019$ & 8940249.18 & 1852936.59 & 4.82 \\
\hline
\end{tabular}

\section{Source: Secondary Data Interpretation:}

The above table shows that the current ratio in the year 2014-15 was 0.99 and then it decreased to 0.66 in the year 2015-2016, further increased to 2.65 in the year 2016-2017 and 2017-2018 it slashed down to 2.15 and finally in the year 2018-2019 it increases to 4.82. The normal current ratio is $2: 1$. The above table shows the last three years the current ratio is normal. This shows that the company is enjoying credit worthiness.

\subsection{Quick Ratio}

This ratio is also known as Quick Ratio or Acid Test Ratio. This ratio is calculated by relating liquid or quick assets to current liabilities. Liquid assets mean those assets which are immediately converted into cash without much loss. All current assets except inventories and prepaid expenses are categorized as liquid assets.

Where,

Quick Asset $=($ Current Asset- Stock - Prepaid

Expenses)

Table No. 4.2 Quick Ratio

\begin{tabular}{|c|c|c|c|}
\hline Year & Quick Asset & $\begin{array}{c}\text { Current } \\
\text { Liabilities }\end{array}$ & Ratio \\
\hline $2014-2015$ & 3393305.5 & 3662645.02 & 0.92 \\
\hline $2015-2016$ & 1804032.42 & 4344770.10 & 0.41 \\
\hline $2016-2017$ & 2821907.55 & 3055104.10 & 0.92 \\
\hline $2017-2018$ & 7100883.38 & 5037069.34 & 1.40 \\
\hline $2018-2019$ & 5591324.59 & 1852936.59 & 3.01 \\
\hline
\end{tabular}

\section{Source: Secondary Data Interpretation:}

The above table shows that the current ratio in the year 2014-2015 was 0.92 and then it decreased to 0.41 in the year 2015-2016, further increased to 0.92 in the year 2016-2017 and 2017-2018 it increased to 1.40 and finally in the year 2018-2019 it increases to 3.01. The normal Quick ratio is $1: 1$. 
The above table shows the last two years the quick ratio is normal. This shows that the company is reasonably good.

\subsection{Gross Profit Ratio}

Gross profit ratio expresses the relationship of gross profit to net sales or turnover. Gross profit is the excess of the proceeds of goods sold and services rendered during a period over their cost, before taking into account administration, selling and distribution and financing charges.

Table No. 4.3 Gross Profit Ratio

\begin{tabular}{|c|c|c|c|}
\hline Year & $\begin{array}{c}\text { Gross } \\
\text { Profit }\end{array}$ & Net Sales & Ratio \\
\hline $2014-2015$ & 4318748.88 & 8464089.6 & 51.02 \\
\hline $2015-2016$ & 5089777.05 & 9441608.5 & 53.90 \\
\hline $2016-2017$ & 7964501.19 & 12748568.6 & 62.47 \\
\hline $2017-2018$ & 6545834.87 & 18142652.7 & 36.07 \\
\hline $2018-2019$ & 6302965.76 & 15870708.6 & 39.71 \\
\hline
\end{tabular}

\section{Source: Secondary Data \\ Interpretation:}

The above table and shows the relationship between the gross profit and net sales in percentage. During 2014-2015 the gross profit position was $51.02 \%$ and in the very next year 2015-2016 it increased to $53.90 \%$ and again in the year $2016-2017$ it raised to $62.47 \%$ and since then 2017-2018 it was decreasing and reached the lowest to $36.07 \%$ in the year 2018-2019 and it was again increasing and finally reached $39.71 \%$. However it can be noticed that the gross profit increase in the year 2016-2017 when compared to previous years.

\subsection{Operating Profit Ratio}

The ratio of all operating expenses (i.e., materials used, labor, factory overheads, and office and selling expenses) to sales is the operating ratio. A comparison of the operating ratio would indicate whether the cost content is high or low in the figure of sales. If the annual comparison shows that the sales have increased, the management would be naturally interested and concerned to know as to which element of the cost has gone up. It is not necessary that the management should be concerned only when the operating ratio goes up. If the operating ratio has fallen, though the unit selling price has remained the same, still the position needs analysis as it may be the sum total of efficiency in certain departments and inefficiency in others. A dynamic management should be interested in making a fuller analysis. It is, therefore, necessary to break up the operating ratio into various cost ratios. The major components of cost are: material, labor and overheads. Generally all these ratios are expressed in terms of percentage. They total up to the Operating Ratio. This, deducted from 100 will be equal to the Net Profit Ratio. If possible, the total expenditure for effecting sales should be divided into two categories, viz., fixed and variable-and then ratios should be worked out. The ratio of variable expenses to sales will be generally constant; that of fixed expenses should fall if sales increase; it will increase if sales fall.

Where,

Operating Profit $=$ Gross Profit - Operating Expenses

Table No. 4.4 Operating Profit Ratio

\begin{tabular}{|c|c|c|c|}
\hline Year & $\begin{array}{c}\text { Operating } \\
\text { Profit }\end{array}$ & Net Sales & Ratio \\
\hline $2014-2015$ & 39015.69 & 8464089.6 & 0.46 \\
\hline $2015-2016$ & 164371.01 & 9441608.5 & 1.74 \\
\hline $2016-2017$ & 308882.80 & 12748568.6 & 2.42 \\
\hline $2017-2018$ & 114927.70 & 18142652.7 & 0.63 \\
\hline $2018-2019$ & 253165.16 & 15870708.60 & 1.59 \\
\hline
\end{tabular}

\section{Source: Secondary Data Interpretation:}

The above table and shows the relationship between the operating profit and net sales in percentage. During 2014-2015 the operating profit position was $0.46 \%$ and in the very next year 2015-2016 it increased to $1.74 \%$ and again in the year $2016-2017$ it raised to $2.42 \%$ and since then $2017-2018$ it was decreasing to $0.63 \%$ in the year 2018-2019 and it was again increasing and finally reached $1.59 \%$.

\subsection{Net Profit Ratio}

One of the components of return on capital employed is the net profit ratio. It indicates the net margin earned in a sale of ${ }^{`} 100$. Net profit is arrived at from gross profit after deducting administration, selling and distribution expenses; non-operating incomes, such as dividends received and non-operating expenses are ignored, since they do not affect efficiency of operations.

Table No. 4.5Net Profit Ratio

\begin{tabular}{|c|c|c|c|}
\hline Year & Net Profit & Net Sales & Ratio \\
\hline $2014-2015$ & 75607 & 8464089.6 & 0.89 \\
\hline $2015-2016$ & $165831 . .01$ & 9441608.5 & 1.75 \\
\hline $2016-2017$ & 279629.32 & 12748568.6 & 2.19 \\
\hline $2017-2018$ & 310297.70 & 18142652.7 & 1.71 \\
\hline $2018-2019$ & 263752.36 & 15870708.60 & 1.66 \\
\hline
\end{tabular}




\section{Source: Secondary Data Interpretation:}

The above table and shows the relationship between the net profit and net sales in percentage. During 2014-2015 the net profit position was $0.89 \%$ and in the very next year 2015-2016 it increased to $1.75 \%$ and again in the year $2016-2017$ it raised to $2.19 \%$ and since then 2017-2018 it was decreasing to $1.71 \%$ in the year 2018-2019 and it was again decreased and finally reached $1.66 \%$.

\subsection{Trend Analysis of Sales}

Sales trend analysis is the review of historical revenue results to detect patterns. Sales trend analysis is a useful budgeting and financial analysis method that can indicate the onset of changes in the near-term revenue growth rates of a business.

Table No. 4.6Trend analysis of Sales

\begin{tabular}{|c|c|c|}
\hline Year & Sales & $\begin{array}{c}\text { Trend } \\
\text { Value }\end{array}$ \\
\hline $2014-2015$ & 9206743.60 & 100 \\
\hline $2015-2016$ & 10242150.5 & 111 \\
\hline $2016-2017$ & 13648568.60 & 148 \\
\hline $2017-2018$ & 19642652.70 & 213 \\
\hline $2018-2019$ & 17306953.60 & 187 \\
\hline
\end{tabular}

\section{Source: Secondary Data}

\section{Interpretation:}

The above table and shows the trend analysis on sales. During 2014-2015 the value was taken as and in the very next year 2015-2016 it increased to 111 and again in the year 2016-2017 it raised to 148 and since then 2017-2018 it was increased to 213 and in the year 2018-2019 and it was decreased to 187 . Based on this analysis we can conclude that 2017-2018 the company position was good by 213 .

\subsection{Trend Analysis of Net Profit}

The general direction of change in net profit over the period of time covered by the net profit trend analysis indicates the profitability progress. An increasing trend indicates that profits are rising and operational efficiency may be improving.

Table No. 4.7 Trend analysis of Net Profit

\begin{tabular}{|c|c|c|}
\hline Year & Net Profit & $\begin{array}{c}\text { Trend } \\
\text { Value }\end{array}$ \\
\hline $2014-2015$ & 75607 & 100 \\
\hline $2015-2016$ & 165831.01 & 219.33 \\
\hline $2016-2017$ & 279629.32 & 369.84 \\
\hline $2017-2018$ & 310297.70 & 410.40 \\
\hline $2018-2019$ & 263752.36 & 348.84 \\
\hline
\end{tabular}

\section{Source: Secondary Data}

\section{Interpretation:}

The above table and shows the trend analysis on net profit. During 2014-2015 the value was taken as 100 and in the very next year 2015-2016 it increased to $219 . .33$ and again in the year 2016-2017 it raised to 369.84 and since then 2017-2018 it was increased to 410.40 and in the year 2018-2019 and it was decreased to 348.84 .

Table No. 4.8

Comparative Balance sheet for the year of 2014-15 \& 2015-2016

\begin{tabular}{|c|c|c|c|c|}
\hline $\begin{array}{c}\text { Partic } \\
\text { ulars }\end{array}$ & $\begin{array}{c}2014-1 \\
5 \text { (Rs) }\end{array}$ & $\begin{array}{c}2015-1 \\
6 \text { (Rs) }\end{array}$ & $\begin{array}{c}\text { Increase/D } \\
\text { ecrease }\end{array}$ & $\begin{array}{c}\text { Percen } \\
\text { tage } \\
(\%)\end{array}$ \\
\hline $\begin{array}{l}\text { Paid } \\
\text { up } \\
\text { capital }\end{array}$ & $\begin{array}{l}30000 \\
0.00\end{array}$ & $\begin{array}{c}30000 \\
0.00\end{array}$ & & 0 \\
\hline $\begin{array}{c}\text { Reserv } \\
\text { es \& } \\
\text { Surplu } \\
\text { s }\end{array}$ & $\begin{array}{c}15023 \\
1.36\end{array}$ & $\begin{array}{c}31606 \\
2.37\end{array}$ & 16583 & $\begin{array}{r}110 \\
-\end{array}$ \\
\hline $\begin{array}{c}\text { Total } \\
\text { reserve } \\
\text { s \& } \\
\text { capital }\end{array}$ & $\begin{array}{l}45023 \\
1.36\end{array}$ & $\begin{array}{c}61606 \\
2.37\end{array}$ & 165831.01 & $\begin{array}{l}36.83 \\
6 \\
6\end{array}$ \\
\hline $\begin{array}{l}\text { Curren } \\
t \text { asset }\end{array}$ & $\begin{array}{l}36343 \\
15.50\end{array}$ & $\begin{array}{l}29108 \\
44.42\end{array}$ & -723471.08 & -19.90 \\
\hline $\begin{array}{l}\text { Fixed } \\
\text { asset }\end{array}$ & $\begin{array}{c}47876 \\
2.88\end{array}$ & $\begin{array}{l}17332 \\
08.88\end{array}$ & 1254446 & 262.01 \\
\hline $\begin{array}{l}\text { Total } \\
\text { asset }\end{array}$ & $\begin{array}{l}41130 \\
78.38\end{array}$ & $\begin{array}{c}46440 \\
53.3\end{array}$ & 530974.92 & 12.90 \\
\hline $\begin{array}{c}\text { Total } \\
\text { curren } \\
t \\
\text { liabiliti } \\
\text { es }\end{array}$ & $\begin{array}{l}36626 \\
45.02\end{array}$ & $\begin{array}{l}43447 \\
70.10\end{array}$ & 682125.08 & 18.62 \\
\hline
\end{tabular}

\section{Source: Secondary Data}

\section{Interpretation:}

The comparative balance sheet of the year 2014-15 and $2015-16$ is as follows. The paid up capital of the company has remain constant. The total reserves $\&$ surplus increased by $36.83 \%$ and it is good for the company growth. The current assets of the company has decreased by $19.90 \%$ and the fixed asset value increased by $262.01 \%$. The liability value also increased by $18.62 \%$. The company should concentrate on decreasing the liability value. 
Table No. 4.9 Comparative Balance sheet for the year of 2015-16 \& 2016-2017

\begin{tabular}{|c|c|c|c|c|}
\hline $\begin{array}{c}\text { Partic } \\
\text { ulars }\end{array}$ & $\begin{array}{c}2015-1 \\
6 \text { (Rs) }\end{array}$ & $\begin{array}{c}2016-1 \\
7 \text { (Rs) }\end{array}$ & $\begin{array}{c}\text { Increase/D } \\
\text { ecrease }\end{array}$ & $\begin{array}{c}\text { Percen } \\
\text { tage } \\
(\%)\end{array}$ \\
\hline $\begin{array}{l}\text { Paid } \\
\text { up } \\
\text { capital }\end{array}$ & $\begin{array}{c}30000 \\
0.00\end{array}$ & $\begin{array}{c}30000 \\
0.00\end{array}$ & 0 & 0 \\
\hline $\begin{array}{c}\text { Reserv } \\
\text { es \& } \\
\text { Surplu } \\
\text { s }\end{array}$ & $\begin{array}{c}31606 \\
2.37\end{array}$ & $\begin{array}{c}59569 \\
1.69\end{array}$ & 279629.32 & \\
\hline $\begin{array}{c}\text { Total } \\
\text { reserve } \\
\text { s \& } \\
\text { capital }\end{array}$ & $\begin{array}{c}61606 \\
2.37\end{array}$ & $\begin{array}{c}89569 \\
1.65\end{array}$ & 279629.28 & 45.38 \\
\hline $\begin{array}{l}\text { Curren } \\
t \text { asset }\end{array}$ & $\begin{array}{c}29108 \\
44.42\end{array}$ & $\begin{array}{c}80966 \\
18.55\end{array}$ & 5185774.13 & 178.15 \\
\hline $\begin{array}{l}\text { Fixed } \\
\text { asset }\end{array}$ & $\begin{array}{l}17332 \\
08.88\end{array}$ & $\begin{array}{l}17991 \\
47.15\end{array}$ & 65938.27 & 3.80 \\
\hline $\begin{array}{l}\text { Total } \\
\text { asset }\end{array}$ & $\begin{array}{c}46440 \\
53.3\end{array}$ & $\begin{array}{c}98957 \\
65.7\end{array}$ & 5251712.4 & 113.08 \\
\hline $\begin{array}{c}\text { Total } \\
\text { curren } \\
t \\
\text { liabiliti } \\
\text { es }\end{array}$ & $\begin{array}{l}43447 \\
70.10\end{array}$ & $\begin{array}{l}30551 \\
04.10\end{array}$ & -1289669 & -29.68 \\
\hline
\end{tabular}

\section{Source: Secondary Data} Interpretation:

The comparative balance sheet of the year 2015-16 and 2016-17 is as follows. The paid up capital of the company has remain constant. The total reserves $\&$ surplus increased by $88.47 \%$ and it is good for the company growth. The total assets of the company has increased by $113.08 \%$. The liability value decreased by $29.68 \%$. The liability value is lower than the previous year. It shows that company is in good position.

Table No. 4.10 Comparative Balance sheet for the year of 2016-17 \& 2017-2018

\begin{tabular}{|c|c|c|c|c|}
\hline $\begin{array}{c}\text { Partic } \\
\text { ulars }\end{array}$ & $\begin{array}{c}\text { 2016- } \\
\mathbf{1 7} \text { (Rs) }\end{array}$ & $\begin{array}{c}\mathbf{2 0 1 7 - 1} \\
\mathbf{8} \text { (Rs) }\end{array}$ & $\begin{array}{c}\text { Increase/D } \\
\text { ecrease }\end{array}$ & $\begin{array}{c}\text { Perce } \\
\text { ntage } \\
\text { (\%) }\end{array}$ \\
\hline $\begin{array}{c}\text { Paid } \\
\text { up } \\
\text { capital }\end{array}$ & $\begin{array}{c}30000 \\
0.00\end{array}$ & $\begin{array}{c}300000 \\
.00\end{array}$ & 0 & 0 \\
\hline $\begin{array}{c}\text { Reserv } \\
\text { es \& } \\
\text { Surplu } \\
\text { s }\end{array}$ & 59569 & 905989 & 310297.7 & 52.09 \\
.39 & & & \\
\hline
\end{tabular}

\begin{tabular}{|c|c|c|c|c|}
\hline $\begin{array}{c}\text { Total } \\
\text { reserv } \\
\text { es \& } \\
\text { capital }\end{array}$ & $\begin{array}{c}89569 \\
1.69\end{array}$ & $\begin{array}{c}120598 \\
9.39\end{array}$ & 310297.7 & 34.64 \\
\hline $\begin{array}{c}\text { Curre } \\
\text { nt } \\
\text { asset }\end{array}$ & $\begin{array}{c}80966 \\
18.55\end{array}$ & $\begin{array}{c}108530 \\
34.28\end{array}$ & $\begin{array}{c}2756416.1 \\
3\end{array}$ & 34.04 \\
\hline $\begin{array}{l}\text { Fixed } \\
\text { asset }\end{array}$ & $\begin{array}{l}17991 \\
47.15 \\
\end{array}$ & $\begin{array}{c}200912 \\
3.15\end{array}$ & 209976 & 11.67 \\
\hline $\begin{array}{l}\text { Total } \\
\text { asset }\end{array}$ & $\begin{array}{c}98957 \\
65.7\end{array}$ & $\begin{array}{c}128621 \\
57.43\end{array}$ & $\begin{array}{c}2966391.7 \\
3\end{array}$ & 29.97 \\
\hline $\begin{array}{c}\text { Total } \\
\text { curren } \\
\mathrm{t} \\
\text { liabiliti } \\
\text { es }\end{array}$ & $\begin{array}{l}30551 \\
04.10\end{array}$ & $\begin{array}{c}503706 \\
9.34\end{array}$ & $\begin{array}{c}1981965.2 \\
4\end{array}$ & 64.87 \\
\hline
\end{tabular}

\section{Source: Secondary Data Interpretation:}

The comparative balance sheet of the year 2016-17 and $2017-18$ is as follows. The paid up capital of the company has remain constant. The total reserves $\&$ surplus increased by $34.64 \%$ and it is good for the company growth. The total assets of the company has increased by $29.97 \%$. The liability value increased by $64.87 \%$. The company should concentrate on decreasing the liability value.

Table No. 4.11

\section{Comparative Balance sheet for the year of 2017-18 \& 2018-2019}

\section{Source: Secondary Data Interpretation:}

The comparative balance sheet of the year 2017-18 and 2018-19 is as follows. The paid up capital of the company has remain constant. The total reserves $\&$ surplus decreased by $2.33 \%$. The total assets of the company has decreased by $16.32 \%$. The company reserves \& surplus and total asset value was not good. The liability value is lower than the previous year with $63.21 \%$ and it good for the company.

\section{FINDINGS}

1. The normal current ratio is $2: 1$. The company last three year was more than $2 \%$. This shows that company is enjoying credit worthiness.

2. The normal Quick ratio is $1: 1$. The company last two year quick ratio is normal. This shows that the company is reasonably good.

3. During the year 2016-17 gross profit ratio was increased to 62.47. Last two year the ratio was 
decreased. The company should focus on increasing the gross profit.

4. The operating profit position of the company has higher expenses than the profit.

5. The net profit and cash ratio was good in the year $2016-2017$ by $2.19 \%$ and 0.15 .

6. Fixed asset turnover ratio was higher in the year 2014-15 by 17.67 and it gets decreased in the following years.

7. The Return on asset ratio shows 2018-19 was performed well with 4.17 .

8. Trend analysis of sales and net profit shows that 2017-2018 company value is higher than the other four years by 213 and 410.40 .

9. Balance sheet shows paid up capital remains constant with 300000 .

10. Comparative balance sheet of the year 2014-15 \& 2015-16 shows asset and liability position was not good and reserves \& capital increased by $36.83 \%$.

11. Comparative balance sheet of the year 2015-16 \& 2016-17 shows asset and liability position was good and reserves \& capital increased by $45.38 \%$ and it is good for the company.

12. Comparative balance sheet of the year 2016-17 $\&$ 2017-18 shows asset position was good and liability position was not good and reserves $\&$ capital increased by $34.64 \%$.

13. Comparative balance sheet of the year 2017-18 \& 2018-19 shows asset was not good and liability position was good because it decreased by $63.21 \%$ and reserves $\&$ capital decreased by $2.33 \%$.

\section{SUGGESSITION:}

1. Last 3 year current ratio was more than $2: 1$ so the company should maintain same value.

2. The company should reduce their operating expenses such as administrative expenses, financial expenses to increase the net profit.

3. The cash ratio position of the company is not satisfactory for the last five years. It is fluctuating over the years and there is no standard ration maintained. So the management should take steps to improving the cash position of the company.

4. Sales value was good in all the year so the company can maintain the same in future years.

\section{RESULTS}

The main objective of the present study is to identify the financial performance and weakness of Pupa Home Care Pvt.Ltd. The company should concentrates on its operating expenses, administrative and selling expenses for more profit. The study reveals that performance was increasing upto the year 2017-18 after it start decreasing its profit and sales. Because of this study I have learnt about practical knowledge on financial calculations such as ratio analysis, trend analysis and comparative balance sheet.

\section{REFERENCES}

[1] Satyanarayana Chary and Sampath Kumar, (2011). Relationship between Working Capital and Profitability - A Statistical Approach, International Journal of Research in Finance \& Marketing, 1(7), 1-16.

[2] Camelia Burja, (2011). Factors Influencing the Companies' Profitability, Annales Universitatis Apulensis Series Oeconomica, 13(2), 215-224.

[3] Tugas, F. C. (2012). A Comparative Analysis of the Financial Ratios of Listed Firms Belonging to the Education Subsector in the Philippines for the Years 2009-2011. International Journal of Business and Social Science,3(21).

[4] Collier, H. W., Grai, T., Haslitt, S., \& McGowan, C. B. (2004). An example of the use of financial ratio analysis: the case of Motorola.

[5] Patel V, Mehta C (2012). A Financial ratio analysis of krishakBharatiCooprerative Limited. International Journal of Marketing, Financial Services \& Management Research. Vol 1 Issue 10 .

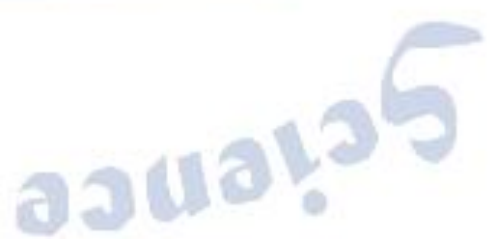

